\title{
Toxic Leadership Behaviour, Followership Characteristics and Their Productivity in Lagos State Senior Secondary Schools, Nigeria
}

\author{
ORUNBON, NURUDEEN OLALEKAN \\ Department of Educational Management, Faculty of Education, Lagos State University, Ojo, Lagos, Nigeria
}

\begin{abstract}
Previous studies have focused on the effective aspects of leadership in education and neglected the toxic aspects of educational leadership which is important to identify the behaviours of school leaders who intentionally and unknowingly inflict enduring damage on their followers and school organisation. Thus, this study examined the relationship between toxic leadership behaviour, followership characteristics and their productivity in Lagos State senior secondary schools. Three hypotheses (tested at 0.05 level of significance). With the study's foundation anchored on correlational and descriptive research designs, its population comprised all Principals, Vice-principals, and teachers in public senior secondary schools in Lagos State. The sample sizes were 98 Principals, 196 Viceprincipals and 980 teachers after stratifying the population into Education Districts and thereafter selected through purposive sampling technique. Analysis was carried out using both descriptive and inferential statistics. Pearsons Product Moment Correlation Analysis and Regression Analysis were used to test the three hypotheses. Findings indicate that a positive and non-significant relationship existed between toxic leadership behaviour and followership commitment to work in Lagos State senior secondary schools $(r=0.025, \rho>0.05)$; the study also found that there was a negative and non-significant relationship between toxic leadership behaviour and followership loyalty in Lagos State senior secondary schools $(r=-0.017, \rho>0.05)$, and the study further found that there is a positive relationship among toxic leadership behaviour, followership commitment to work, and followership loyalty with followership productivity in Lagos State senior secondary schools. It is concluded that toxic leadership is present in Lagos State public senior secondary schools, as evidenced in the study. The study therefore recommended that school teachers should be exposed to professional development training and opportunities particularly in leadership before placement for leadership positions, as leadership preparation and training are central to school effectiveness and school improvement, and qualified consultants with expertise in organisational leadership should be engaged during the search and selection processes of school leaders so as to detect toxic leaders in waiting.
\end{abstract}

Keywords: Toxic Leadership Behaviour, Followership Characteristics, Followership Commitment, Followership Loyalty, Productivity.

DOI: $10.7176 / \mathrm{JEP} / 11-11-05$

Publication date: April $30^{\text {th }} 2020$

\subsection{Introduction}

Leadership is important in human organisations including the school. Leadership is then an essential factor in effective school management. That is why time and the production equation in industries and other human groups have gone beyond money, machine and market to include adequately trained personnel particularly the leadership of organisations (Oyegoke, 2012). School leadership has become a priority in education policy agenda internationally. School leadership plays a key role in improving school outcomes by influencing the motivations and capacities of teachers, as well as the school climate and environment. Effective school leadership is essential in improving the efficiency and equity of schooling.

Leadership, therefore, is the catalyst for change and effectiveness of the school system as an organisation. Leadership ineffectiveness has been responsible for the major challenge to goal achievement and to the decay of most secondary schools in most states in Nigeria. Ibukun (2008) had observed that secondary schools have derailed in the provision of qualitative education expected of them. Ibukun further explained that, a lot of problems seem to bedevil the system thereby making it ineffective; hence schools need to be provided with the appropriate leadership in order to meet the yearnings and aspirations of the people.

Overall, it is important that school leaders have to be held to a higher standard since they are responsible not just for themselves, but for the teachers and students they work together with. School leaders are the ones who have the decision-making instruments to organise positive and helpful active moves in the people in a school organisation; but there are times, where they choose to use the instruments to just apply their own sense of control or self-serving motives.

Still, the success or failure of organisations, including educational institutions, is a result of both the leaders and followers' roles (Avolio \& Richard, 2008). The role of followers, therefore, can no longer be ignored especially with the realization that followers actually get the job done. Followers are as important as leaders, yet in 
management and organisational behaviour literature, the focus is largely on the concept of leadership (Shondrick \& Lord 2010). It is then believed that a focus on followership will enhance the understanding of the leadership process because the operation of each is dependent on the other (Henry, 2012). Thus, in order for leaders to succeed in their dealings, they must teach their followers how to lead by delegating duties and responsibilities to them and how to be good followers. It is therefore necessary to promote result-oriented followership in order to achieve educational goals.

Various adjectives have been used till date to qualify leadership and hence to define and describe leadership styles and behaviours. One of these and among the most recent is toxic leadership.

School leadership and followership are central to enhanced quality education and productivity in senior secondary schools. Meanwhile, research on leadership has not been balanced with respect to bad and good leaders; the majority of studies have focused on the positive aspects of leadership in education more than the negative ones. Although an understanding of positive leadership is vital for developing education managers, it is equally important to identify the behaviours of education leaders who intentionally or unknowingly inflict enduring damage on their followers and school organisation. That is, toxic leadership behaviour in education reflects the noticeable absence of effective and authentic leadership quality among school leaders which includes phenomenon like managerial incompetence and managerial misconduct.

\subsection{Statement of the Problem}

School leadership and followership are central to enhanced quality education and productivity in senior secondary schools. Principals' leadership role in the school system and the issue of leadership are therefore crucial to the attainment of goals, aims and objectives of the school. Thus, school leadership has become a priority in education policy agenda globally and plays a key role in improving school outcomes by influencing the motivation and productivity of teachers. It then becomes imperative not only to examine the leadership context but also to look into the followership meaning and practice especially that leadership and followership are two sides of the same coin.

Meanwhile, research on leadership has not been balanced with respect to bad and good leaders; the majority of studies have focused on the positive aspects of leadership in education more than the negative ones. Although an understanding of positive leadership is vital for developing education managers, it is equally important to identify the behaviours of education leaders who intentionally or unknowingly inflict enduring damage on their followers and school organisation.

Moreover, ineffective (or poor) leadership must be viewed as not merely a lack of positive behaviours, but also a display of specifically destructive behaviours (Toor \& Ogunlana, 2009). It could be observed that research on required leadership behaviours has enabled leaders in public senior secondary school settings to attempt to adapt and align their behaviour to reflect frequently accepted leadership qualities. Such alignment, although influenced heavily by positive and constructive leadership research, thereby looks down upon the lessons and opportunities that may be generated by research on the side of leadership such as toxic leadership behaviour.

Not many studies therefore, seem to have been directed at toxic leadership and not many studies seem to have similarly been focused at followership characteristics. Regardless of findings and the notion that toxic leadership has found an essential place in recent leadership studies, such trends have not spread into the educational leadership sector.

At present, it seems there is little for public school leaders to learn in terms of the types of behaviours that should be discouraged in the schools among the school leaders. In the same vein, fewer studies, if any seem to have been targeted at the relationship between toxic leadership, followership characteristics and productivity at the senior secondary school level. This relationship presents the problem for this study albeit, in public senior secondary schools in Lagos State.

\subsection{Purpose of the Study}

The purpose of this study was to examine the relationship between toxic leadership behaviour, followership characteristics and their productivity in public senior secondary schools in Lagos State. In specific and explicit terms, this study was set out to:

1. find out the relationship between toxic leadership behaviour and followership commitment to work in Lagos state senior secondary schools.

2. examine toxic leadership behaviour and followership loyalty in Lagos State Senior Secondary schools.

3. find out the relationship among toxic leadership behaviour, followership commitment to work, and followership loyalty with followership productivity in Lagos State senior secondary schools.

\subsection{Research Questions}

The following questions were raised to guide this study:

1. Is followership commitment to work related to toxic leadership behaviour in Lagos state public senior 
secondary schools?

2. Does toxic leadership behaviour relate with followership loyalty in Lagos State senior secondary schools?

3. What is the relationship among toxic leadership behaviour, followership commitment to work, and followership loyalty with followership productivity in Lagos State senior secondary schools?

\subsection{Research Hypotheses}

The following research hypotheses were proposed and tested in the study:

Ho1: There is no significant relationship between toxic leadership behaviour and followership commitment to work in Lagos state senior secondary schools.

Ho2: There is no significant relationship between toxic leadership behaviour and followership loyalty in Lagos State senior secondary schools.

Ho3: There is no significant relationship among toxic leadership behaviour, followership commitment to work, and followership loyalty with followership productivity in Lagos State senior secondary schools.

\subsection{Theoretical Framework: Leader-Member Exchange (LMX) Theory}

The Leader-Member Exchange (LMX) theory was developed by Dansereau, Graen and Haga in 1975. It conceptualizes leadership as a process of interaction between leaders and followers and centres on the dyadic exchange relationships between both. LMX theory is a relationship-based approach to leadership that projects the relationship between leaders and members as the central concept of the leadership processes (Northouse, 2013). Leader-member exchange (LMX) theory can also be regarded as a transactional theory of leadership in that the emphasis is on the relationship that exists when one person leads and another follows; and on the transactions that occur in order to attain equity with regard to the provision of resources (Hogg, 2004). It is a relationship based approach to leadership that focuses on the two-way (dyadic) relationship between leaders and followers. It suggests that leaders develop an exchange with each of their subordinates, and that the quality of these leader-member exchange relationships influences subordinate responsibility, decisions and access to resources and performance (Tayla \& Berrin, 2015).

According to the leader-member exchange (LMX) theory, it is significant to strengthen the interactions among the three domains of leadership: the leader, the follower and the dyadic relationship of which influence leadership outcomes. The theory directs managers or leaders to focus their leading role on relationship perspective and also suggest how they can improve their roles through building quality relationships with their followers (Northouse, 2007). The leader-follower relationships within work groups are split up into a set of working relationships between a leader and the various members of the work team since it is assumed that different relationships between the leader and every single follower develop. Hence, the leader may have different types of transactions and different kinds of relations with different followers (Van Breukelen, Schyns \& Le Blanc, 2006).

The goal of Leader-Member Exchange (LMX) theory is to explain the effect of leadership on members, teams, and organisations. According to the theory leaders form strong trust, emotional and respect based relationships with some members of a team, but not with others (David and Darja, 2016). Leader-Member Exchange (LMX) theory claims that leaders do not treat each subordinate the same. The work-related attitudes and behaviours of those subordinates depend on how they are treated by their leader (Rockstuhl, Dulebohn, Augustine, \& Shore, 2012).

\subsection{Review of Literature \\ Toxic Leadership}

A toxic leader is defined as an individual whose destructive behaviour and dysfunctional personality characteristics generate serious and enduring poisonous effects on those he/she leads. Intentionality plays a part in determining an individual's level of toxicity. For example, an intentional toxic leader will deliberately harm others or enhance themselves at others' expense. Unintentionally toxic leaders cause serious harm by careless or reckless behaviour, as well as by their incompetence (Lipman-Blumen, 2010).

The term "toxic leader" first appeared in 1996 (Wicker, 1996), but as yet no standard definition of toxic leadership exists. Nevertheless, toxic leadership is an increasingly prevalent phenomenon in today's world, affecting both private and public organisations and individuals in all fields of social life, from business, education and politics to various other domains of action (Padila, Hogan \& Kaiser, 2007). Toxic leaders, through the negative impact of their decisions and actions, are one of the main sources - if not the most important one- of dysfunctional behaviours, policies, programmes in any entity (group, organisation or society). In spite of the increased importance gained by the subject among various management specialists, experts are having hard times defining, detecting and explaining toxic leadership (Lipman-Blumen, 2005).

The term toxic leader refers to leaders who display five specific characteristics, which are: Self-promotion, Abusive supervision, Unpredictability, Narcissism and Authoritarian leadership (Schmidt, 2008). The toxic leader completes short term requirements by operating at the bottom of the continuum of commitment, where followers 
respond to the positional power of their leader to fulfil requests. Prolonged use of toxic leadership to influence followers undermines the followers' will, initiative and potential and destroys unit morale (Reed, 2004).

Once a toxic leader is hired, and the required level of productivity is reached, negative results typically follow (Illies and Reiter-Palmon, 2008; Lipman-Blumen, 2005; Tepper, 2010). Those results are as follows: (a) rebellion in the workplace, (b) employee termination, (c) lost tacit knowledge, (d) eventually lower productivity, and (e) higher cost to motivate employees (Dotlich and Cairo, 2003). That is, toxic leadership behaviour in education reflects the noticeable absence of effective and reliable leadership quality among school leaders which includes phenomenon like managerial incompetence and managerial misconduct.

Researchers widely recognise that followership is an emerging concept. Followers are subordinates who have less power, authority, and influence than do their superiors and who, therefore, usually, but not invariably, fall in to line (Kellerman, 2008).

Prolonged use of toxic leadership to influence followers undermines the followers' will, initiative, and potential and destroys unit morale.

First, toxic leaders exhibit an underlying neglect for the well-being of their subordinates, and may even be harmful or abusive (Lipman-Blumen, 2005, and Wilson-Starks, 2003). Many toxic leadership articles include stories of leaders who berate, belittle, and bully their subordinates, who hold subordinates responsible for things beyond their control or tasks beyond their job descriptions, and who cause their subordinates to work harder and sacrifice more than is reasonable (Frost, 2004; Wilson-Starks, 2003).

A second theme is exemplified by micromanaging to the point where subordinates are cowered and stifled. Lipman-Blumen (2005) described this as "stifling constructive criticism and teaching supporters (sometimes by threats and authoritarianism) to comply with, rather than to question, the leader's judgment and actions" and Wilson-Starks (2003) wrote "in a toxic leadership environment, 'yes' people are rewarded and promoted to leadership roles, while people who more fully engage their mental resources, critical thinking, and questioning skills are shut out from decision-making and positions of influence". Other anecdotes included leaders who demand obedience and who are commandeering.

A third common theme indicates that toxic leaders are narcissistic. They have a need to be viewed in a positive light by others coupled with a desire to enhance their own self-image. Toxic leaders were often described as being self-interested, lacking empathy or sensitivity for others, and having inflated opinions of their own importance.

Not all toxic leaders are totally ineffective, however. Many are extremely successful in results. Steele (2011) noted that toxic leaders are usually not incompetent or ineffective leaders in terms of accomplishing explicit mission objectives. He said many times they are strong leaders who have the right stuff, but just in the wrong intensity, and with the wrong desired end-state, namely self-promotion above all else.

Toxic leaders, Egan (2004) reported different types of toxic leaders as accidental, destructive-narcissistic, and psychopathic leaders. Accidental toxic leaders were those who are truly unaware of the effect of toxic actions on others (Egan, 2004). This type of toxic leader caused harm by lacking patience or using inappropriate comments or actions towards others. When confronted, this type of toxic leader apologized and retreated from his or her behaviours (Egan, 2004). Destructive-narcissistic toxic leaders were those who portray themselves as possessing self-importance, causing others to perceive them as acting superior and self-domineering. Egan claimed that toxic behaviours made the leaders manipulate and exploit others to move ahead and attain ideal fantasies. Though this type of toxic leader is very reluctant to change, he or she may change with time and persistence. Finally, psychopathic toxic leaders bullied others for fun and lacked feelings of remorse, guilt or empathy (Mathieu \& Baniak, 2016). This type of toxic leader was the most dangerous because he or she lacked insight into personal behaviours and were unwilling to change (Egan, 2004).

\section{Followership}

Followership can thus serve as an effective process in harnessing organisational change, as effective followers impact the adaptive culture of an organisation through both challenging and supporting leaders (Chaleff, 2008). In essence, followership impacts on leadership and hence on the organisational process as well as organisational output and productivity.

\section{Types of Followership}

1. Sycophants: The flatters, "yes people". They cannot be relied upon to give critical feedback if the leader is heading in a direction that conflict with the purpose or values of the organisation. They never point out problems or raise objections; they will avoid any resistance and will defer to the leader.

2. Critics: The opposition. The detractor's goal is to challenge and question the leader's every behaviour and policy. They can be classified as disgruntled, perhaps for some reason they were not recognised, awarded a promotion they felt they deserved. They are frequently the first to greet new employees and tell them "how things really work around here".

3. Realists: Provide constructive critical thinking and interact with the group and the leader. If they agree with the current course of action, they will back the leader $100 \%$. Alternatively, if they disagree, they will challenge the leader, offering constructive alternatives to help the leader and organisation achieve their aims. 
4. Loyalists: The genuine supporters. They are highly engaged and work hard to support the leader. They are reliable and dependable. They are highly satisfied and productive and are passionate about the team and will exert considerable effort to make it successful by always giving suggestions.

5. Traitors: The silent haters and conspirators. They are very good actors. They are hard to spot (until it is too late) as they have gained the leader's trust. They have strong negative emotional feelings about the leader and secretly work to undermine him/her.

6. Spectators: The observers. They are neither here nor there and just stand on the side lines. They just work for their salary and do not get involved. They are disengaged with the organisation or task and hold a position of neutrality about the leader.

7. Opportunists: The freebooters. They have a price and can easily be bought. They like to be close to the powerful and their allegiance is to whenever is on top at the moment. They are always in search of good things in the organisation and they love power (Hyacinth, 2014).

Spectators do their job and nothing more. They are passive. Opportunists do everything openly to get noticed and love to be rewarded. They see the leader as a means to an end (promotion). Traitors are treacherous and inflict the deepest wounds. In the case of some negative event they are quick to publicly denounce the leader.

Be wary of sycophants, they are not truthful and can set the leader up for a great fall. Although one can count on loyalists to get the job done, due to their biased admiration for the leader, they can provide the leader with misguided feedback in their assessment of his/her talents and abilities. They are good have close especially in low moments such as failed projects or poor performance to give much needed reassurance.

However, Campbell (2002) observed that a man works well when he is happy with his facilities and equipment, happy with the people he works with and safe and secure with his tools or machines, that a man works well when his superior takes note of his contribution or importance to the organisation and reinforces him that a man works when there is no highhandedness and there is equal justice.

Campbell (2002) therefore explains the following followers' attitude to work:

The loyalist: Shows real obedience and respect for their leaders. They follow and obey any instruction given by the authority. They aim of quietly rising to the zenith of their career. They strive at excellence to get promotion in the organisation. They are reliable and trustworthy.

The Bargainers: They discuss matters with the authority through dialogue and compromise. They like their work but would not like to be exploited. They avoid risking their job and are ready to meet the administration halfway in their demands.

The Vegetators: These report simply for duty, put in a day's pay. They are not worried about their welfare. They are like vegetables in the garden waiting to be watered and pruned. They lack innovation or improved skill. They hardly have lesson notes or keep school records. Their interest is only in their pay.

The Agitators: These have negative attitudes to work. Always complaining about the authority. Never satisfied with their condition. Always grumbling. They spend considerable time talking ill of the leaders. They talk others not to put in their best. Most agitators are sometimes vegetators.

The Rejectors: They are too outspoken and may stage a strike in the organisation. They work like mercenaries who will put in their best only if the reward is good. They are not innovative and may reject new ideals and techniques that will improve their productivity.

\subsection{Teachers' Commitment}

In the present study, organisational commitment is viewed as the teacher's commitment to the local school or school division. Educational organisation such as schools, colleges and universities require individuals who committed to their profession and well-being of students.

Teacher commitment is regarded as a key concern in educational systems across the globe, because of its influence on student outcomes and general school effectiveness (Park, 2005).

The vitality of all educational organisations lies in the willingness to teachers to contribute to the development of the organisations. Teachers strong in commitment find it easy to be interested in whatever they are doing and can involve themselves into it wholeheartedly. They are rarely at a loss for things to do. Committed teachers always seem to make maximum effort cheerfully and zestfully.

Nir (2002) posited three types of teacher commitment, commitment to teaching, commitment to students, and commitment to organisation. Other researchers have used other terms to define organisational commitment and have coined the phrase discretionary effort (Voluntary and discretionary behaviours that exceed formal expectations of the job) and assert that it is a vital component of worker commitment in general and specifically teacher commitment, which is in turn influenced by the quality of leadership provided (Hoy, Hoy \& Kurz, 2008). From the literature the consensus is that conceptualization of teacher commitment can be synthesised as a multidimensional construct that is reflected in four dimensions as follows; commitment to students, commitment to teaching, commitment to school, and commitment to students, commitment to teaching, commitment to school, and commitment to profession (Thien, Razak \& Ramayah, 2014). Ibrahim, Ghavifekr. Ling, Siraj and Azeez (2013) 
teachers may vary in their commitment to the school as an organisation, the students, or teaching as a profession.

\subsection{Teachers' Loyalty}

Loyalty means the realization of cohesion, the complete recognition that one fails or succeeds dies or live, are damned or saved together. The employee's loyalty is a more action-oriented concept since it deals with the behaviour of the employees. Employee loyalty includes such things as whether or not employees are committed and assumes personal responsibility for their work and whether or not they feel convinced to look for another job opportunity (Carmen \& Teodora, 2012). The related literature offers an interesting set of indicators of loyalty; not leaving, remaining with the institution, staying late to complete a project, no whistle blowing, no job hunting, promoting the institution to clientele and community, no gossiping, keeping the institution's matters confidential, no lying, cheating or stealing, adhering to rules without close supervision, offering improvement suggestions, sacrificing personal goals to achieve institution's goals, participating in institution's extracurricular activities, taking care of institution property, working safety, following orders, not abusing leave policies and not being wasteful including sick leave and cooperating with co-workers (Kemi, 2014).

Based on a study conducted in a Chinese setting, Chen, Tsui and Farh (2002) suggested that loyalty to supervisor is composed of five dimensions. The first of the dimensions is dedication. That includes subordinate's willingness to dedicate him or herself to the supervisor and to protect the supervisor's welfare even at the expense of personal interests. The second dimension is effort. This dimension contains a subordinate's willingness to exert considerable effort on behalf of the supervisor. The third dimension is following supervisor. This dimension includes subordinate's respect for the accomplishments of the supervisor, and a feeling of pride in being a subordinate to that supervisor. And the last dimension is internalization. It refers to value congruence between the subordinate and the supervisor.

\section{Teachers' Productivity}

Productivity is a concept that applies to all aspects of life and therefore means different things to different people (Adu, Oshati \& Eze, 2012). A general definition is that productivity is the relationship between the output generated by a production or service system and the input provided to create this output. Thus productivity is defined as the efficient and effective utilization of resources- labour, capital, land, materials, energy, information, in the production of various goods and services.

Productivity is an overall measure of the ability to produce a good or service. More specifically, productivity is the measure of how specified resources are managed to accomplish timely objectives as stated in terms of quantity and quality. Productivity may also be defined as an index that measures output (goods and services) relative to the input (labour, materials, energy, etc., used to produce the output). Productivity is a required tool in evaluating and monitoring the performance of an organisation, including education sector (Kennedy, 2016).

Productivity of an organisation is defined as the ratio of outputs produced by the organisation and the resources consumed in the process. Productivity is a required tool in evaluating and monitoring the performance of an organisation, including education sector (Edo \& Nwosu, 2018).

Meanwhile, Inatimi (2018) sees productivity as a ratio to measure how well an organization (individual, industry or country) converts input resources (labour, materials, machines etc.) into goods and services. Productivity is the result achieved from output over input; it is the optimal utilization of existing resources to meet the set targets. Productivity reduces wastages and brings about sustainable quality through proper harnessing of work efforts using different methods such as shared responsibility, team work, capacity building and motivation to induce workers to realize the organization's objectives.

In the school system, teachers' productivity could be measured in terms of teacher's performance. Teachers' productivity is the ratio of output produced by the teachers; here the output refers to the quality of the students produced or turned out on yearly basis (Musibau \& Adigun, 2010). Teachers' productivity level may also be evaluated in terms of what the teachers control and actually do in the classroom such as effective teaching, classroom management and performance (Dunkin, 1997). The major tool (indicators) of school performance is student academic performance, most especially at the external level. If the majority of student presented for WAEC/NECO examination have below five credits the performance is low, it shows the level of teachers' productivity. But if the majority has above five credits, the performance is rated high (Atanda \& Waheed, 2006).

Also, Owoeye in Kennedy (2016) asserted that variables of teachers' productivity such as effective teaching, lesson note preparation, effective use of scheme of work, effective supervision, monitoring of students "e work and disciplinary ability are virtues which teachers should uphold effectively in the school system. As revealed by Purcell, Kinnie, Hutchinson, Rayton and Swart (2003) evidence shows that teacher productivity depended on having the right mix of the skills, abilities, motivation and potentialities in achieving the predetermined goal of the institutions.

Therefore, teacher productivity in many studies has been associated with output or end-result of the school academic engagements such as internal examinations like end of term result, school mock examination, WAEC or NECO results. 


\section{Methodology}

In the choice of a design for this study, correlational and descriptive survey research designs were considered suitable. This is because the study examined the nature of relationship between toxic leadership behaviour and followership characteristics and a description of existing situation regarding the emergence of toxic leadership behaviour in public senior secondary schools in Lagos State and its concomitant influence on followership characteristics and their productivity in Lagos State public senior secondary schools. The study also described the interplay between the variables.

The study population comprised all Lagos State owned senior secondary schools in the six Education Districts in State. The study population also consisted of all the principals, vice-principals, and teachers of these schools.

The stratified random sampling technique was used to select $30 \%$ of total number of public senior secondary schools of Lagos State. That is, for the teachers and principals, 30 percent of them were chosen after stratifying into Education Districts.

Again, a purposive sampling technique was employed to select one principal, the two vice-principals, and ten teachers teaching and taking students through SS I to SS III to be drawn from each school.

It was purposive in that, principals, vice-principal, and teachers that have stayed or have been teaching in their various schools for five years were selected as participants in the study.

Therefore, a total of 98 principals, 196 vice-principals, and 980 teachers were used for the study. However, the selection of respondents from each Education District was on an equal basis.

Two research instruments were used for the study. They are self-structured and developed questionnaires by the researcher in conjunction with experts on the field of measurement and evaluation. They questionnaires were responded to by the school Principals, the two Vice-Principals, and teachers. These instruments were used to elicit information from respondents regarding toxic leadership behaviour and followership characteristics.

Record observation of student results, West African Senior School Certificate Examination (WASSCE) 2013 -2017 was used to measure followership productivity.

Data collected were analysed using both descriptive and inferential statistics. Descriptive statistics used included tables, charts, figures and percentages. Inferential statistics used were correlation analysis for testing hypotheses 1 and 2, and regression analysis for testing hypothesis 3 at 0.05 level of significance through the aid of Statistical Package for Social Sciences (SPSS) version 24.0.

\subsection{Results}

\section{Descriptive Analysis of Followership Characteristics}

This presents descriptive statistics analysis to the items on followership characteristics in the selected senior secondary schools in Lagos State. The followership characteristics considered in this study include followership commitment to work, followership loyalty, and followership productivity. The average mean and standard deviation of the scores on each dimension of followership are presented in Table 1.

\section{Table 1}

Followership Dimension
Commitment at work
Loyalty
Productivity
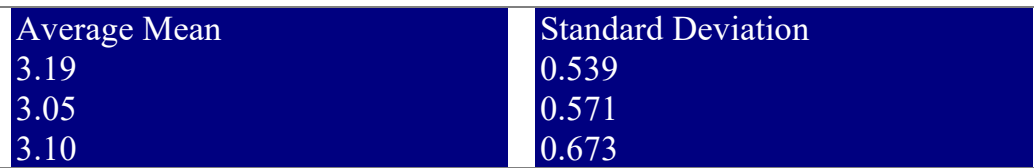

The grand mean for followership productivity is 3.10 that followership productivity is greater than 2.50 and positive. This is further corroborated by a grand standard deviation of 0.673 which reveals a similarity in respondents' opinions tending towards the mean value.

\section{Descriptive Statistics of Toxic Leadership}

This presents the descriptive analysis on toxic leadership behaviour to indicate if principals and vice-principals do exhibit this in some situations in school. The overall results showed that school leaders in most public senior secondary school in Lagos State often exhibit toxic leadership behaviours in their interactions with the followers (teachers most especially) with a grand mean of 2.86 and this is further corroborated by a grand standard deviation of 0.939 which reveals a similarity in respondents' perceptions moving towards the mean value. This could impact negatively on the followership loyalty, commitment to work, and productivity.

\section{Hypothesis One}

This hypothesis states that 'there is no significant relationship between toxic leadership behaviour and followership commitment to work in Lagos state senior secondary schools". In order to test the hypothesis, Pearson's productMoment Correlation analysis was used. The data collected on toxic leadership behaviour and followership commitment to work were subjected to the analysis. The results are presented in Table 2 
Table 2

Correlation showing relationship between toxic leadership behaviour and followership commitment to work in public senior secondary schools
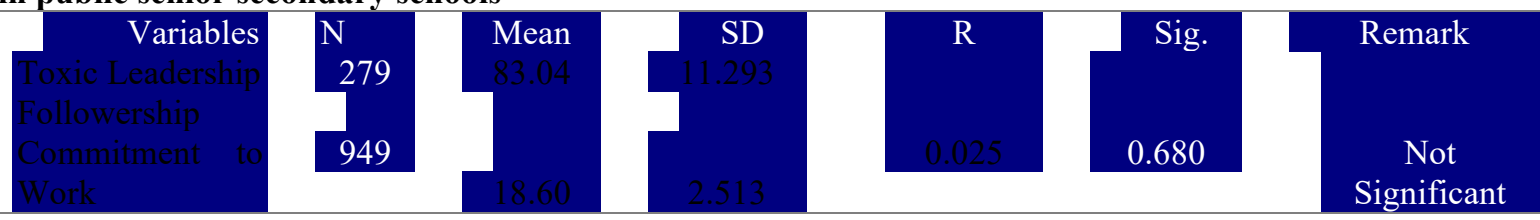

Source: Field Work

The Table 2 shows that that there is a positive and non-significant relationship between toxic leadership behaviour and followership commitment to work in Lagos State senior secondary schools $(r=0.025, \rho>0.05)$. This implies that toxic leadership behaviour does not significantly influence commitment to work of the teachers in Lagos State senior secondary schools. Therefore, the hypothesis which states that there is no significant relationship between toxic leadership behaviour and followership commitment to work in Lagos state senior secondary schools is hereby not rejected.

Hypothesis Two

This hypothesis states that 'there is no significant relationship between toxic leadership behaviour and followership loyalty in Lagos State senior secondary schools". To test this hypothesis, data collected on toxic leadership behaviour and followership loyalty were subjected to Pearson's Product-Moment Correlation Analysis. The results are presented in Table 3.

Table 3

Correlation showing relationship between toxic leadership behaviour and followership loyalty in public senior secondary schools
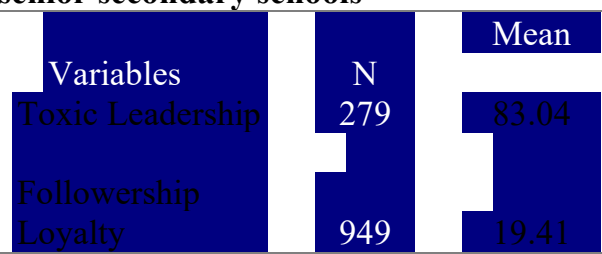

\section{SD}

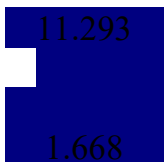

Sig.

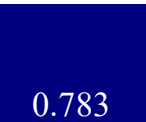

Remark

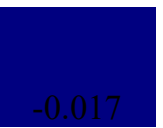

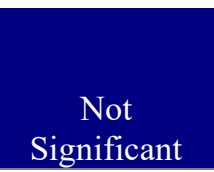

Significant

\section{Source: Field Work (2019)}

The result in Table 3 shows that there is a negative and non-significant relationship between toxic leadership behaviour and followership loyalty in Lagos State senior secondary schools $(r=-0.017, \rho>0.05)$. This implies that the higher the toxic leadership behaviour, the lower the followership loyalty. The result suggests that toxic leadership behaviour does not significantly influence teachers' loyalty in Lagos State senior secondary schools. Therefore, the hypothesis which states that there is no significant relationship between toxic leadership behaviour and followership loyalty in Lagos State senior secondary schools is hereby not rejected.

Hypothesis Three

This hypothesis states that 'there is no significant relationship among toxic leadership behaviour, followership commitment to work, and followership loyalty with followership productivity in Lagos State senior secondary schools". To test the hypothesis, multiple regression analysis was used. Data on toxic leadership behaviour, followership commitment to work, followership loyalty, and productivity were therefore subjected to multiple regression analysis and the results of the analysis are presented in Table 4.

Relationship among toxic leadership behaviour, followership commitment to work, and followership loyalty on their productivity

Table 4.1Model Summary of Regression

\begin{tabular}{|l|c|c|c|c|}
\hline \multicolumn{5}{|c|}{ Model Summary } \\
\hline Model & R & R Square & Adjusted R Square & Std. Error of the Estimate \\
\hline 1 & $0.563^{\text {a }}$ & 0.317 & 0.307 & 1.482 \\
\hline a. Predictors: (Constant), Followership Commitment at Work, Toxic Leadership, and Followership Loyalty. \\
\hline
\end{tabular}

Table 4.2ANOVA of Regression Analysis

\begin{tabular}{|l|l|r|r|r|r|c|}
\hline \multicolumn{7}{|c|}{ ANOVA $^{\mathrm{a}}$} \\
\hline Model & Sum of Squares & Df & Mean Square & F & Sig. \\
\hline \multirow{3}{*}{1} & Regression & 279.217 & 4 & 69.804 & 31.804 & $0.000^{\text {b }}$ \\
\cline { 2 - 7 } & Residual & 601.392 & 274 & 2.195 & & \\
\cline { 2 - 7 } & Total & 880.609 & 278 & & & \\
\hline
\end{tabular}


Table 4.3Coefficients of Regression

\begin{tabular}{|c|c|c|c|c|c|c|}
\hline \multicolumn{7}{|c|}{ Coefficients $^{\mathrm{a}}$} \\
\hline \multirow{2}{*}{\multicolumn{2}{|c|}{ Model }} & \multicolumn{2}{|c|}{$\begin{array}{l}\text { Unstandardized } \\
\text { Coefficients }\end{array}$} & \multirow{2}{*}{$\begin{array}{c}\text { Standardized } \\
\text { Coefficients } \\
\text { Beta }\end{array}$} & \multirow[t]{2}{*}{$\mathrm{T}$} & \multirow[t]{2}{*}{ Sig. } \\
\hline & & $\mathrm{B}$ & Std. Error & & & \\
\hline \multirow[t]{4}{*}{1} & (Constant) & 6.405 & 1.447 & & 4.428 & .000 \\
\hline & Toxic Leadership & -.0009 & 0.009 & -0.050 & $\overline{0} .992$ & 0.322 \\
\hline & Followership Loyalty & 0.376 & 0.059 & 0.352 & 6.371 & 0.000 \\
\hline & $\begin{array}{l}\text { Followership Commitment at } \\
\text { Work }\end{array}$ & 0.094 & 0.036 & 0.133 & 2.609 & 0.010 \\
\hline
\end{tabular}

\section{Source: Field Work (2019)}

Table 4.1, 4.2 and 4.3 presents the statistical model summary on the relationship among toxic leadership behaviour, followership commitment to work, and followership loyalty with followership productivity in Lagos State senior secondary schools. The results show that there is a positive relationship among toxic leadership behaviour, followership commitment to work, and followership loyalty with followership productivity in Lagos State senior secondary schools. Correlation coefficient $(\mathrm{R})$ is 0.563 . The relationship among toxic leadership behaviour, followership commitment to work, and followership loyalty followership productivity is moderately strong. The results further indicate that there are different variations in productivity by toxic leadership behaviour, followership commitment to work, and followership loyalty. The coefficient of determination, $\mathrm{R}^{2}=0.317$ explains that $31.7 \%$ of the variations of productivity have been explained by toxic leadership behaviour, followership commitment to work, and followership loyalty while $68.3 \%$ of the variations are explained by other factors, which are not part of this study.

Furthermore, the results of F statistics is 31.804 and $p=0.000$ which is less than 0.05 level of significance suggesting that, over all, the regression model statistically significantly predicted the outcome variable productivity. Moreover, the analysis revealed that followership loyalty $(\beta=0.376, p<0.05)$, and followership commitment at work $(\beta=0.094, \mathrm{P}<0.05)$ were found to have statistically and significant joint influence on followership productivity. The findings indicated that, compared to the other two key variables (toxic leadership, and followership commitment at work), followership loyalty has the strongest influence on the followership productivity in Lagos State senior secondary schools. Lastly, the study found that toxic leadership $(\beta=-0.009$, $\mathrm{p}>0.05$ ) did not significantly influence followership productivity. From the results, toxic leadership has a negative and insignificant influence on the followership productivity in Lagos State senior secondary schools.

Therefore, there is significant relationship among toxic leadership behaviour, followership commitment to work, and followership loyalty with followership productivity in Lagos State senior secondary schools. Based on the findings, the null hypothesis which states that there is no significant relationship among toxic leadership behaviour, followership commitment to work, and followership loyalty with followership productivity in Lagos State senior secondary schools was rejected.

\subsection{Discussion}

This study also found that there is a positive and non-significant relationship between toxic leadership behaviour and followership commitment to work in Lagos State senior secondary schools. The result concurred with that of Mehta and Maheshwari (2013) who reported that toxic leadership creates an insecure organisational environment, and commitment on the part of followership is usually decreased. Toxic Leaders leads to many negative outputs in the workplace, not only by means of the decreasing organizational commitment but also the decreasing workplace performance of employees (Kilic \& Gunsel, 2019). Aboyassin and Abood (2013) and Burns, (2017) also corroborated with this finding when they submitted that toxic leadership decreases employee's commitment. Also, Kusy and Holloway (2009) submitted that toxic leadership usually attacks self-esteem and self-efficacy of the followers which ultimately leading to deterioration in followers' commitment to work within the organisation. Hadadian and Zarei (2016) also corroborated this finding when they reported that toxic leadership usually affects committed teachers in performing their roles effectively as required by their job and in establishing a good teacherstudent relationship in accordance with professional values. Toxic leaders often come to life in toxic organisations, and toxicity within an organisation erodes productivity, motivation, creativity, and commitment (Isikay, 2019). Kuenzi, Mayer, and Greenbaum's (2019) study found that ethical leaders model appropriate behaviour, communicate ethical standards, and punish or reward employees based on ethical compliance. On contrary, unethical leaders (toxic leaders) tend not to make fair and balanced decisions and do not encourage employees to consider 'what is right thing to do' when making decisions, thus affecting followership commitment and productivity.

The study further found that there is a negative and non-significant relationship between toxic leadership 
behaviour and followership loyalty in Lagos State Senior Secondary Schools. This finding is in agreement with that of Pelletier (2010) who found that toxic leadership had negative direct effects on followership loyalty, work group productivity and organisational commitment. Other studies by Mullins (2002), also noted that toxic principals believe in authority to get things done; this hinders teacher loyalty and creativity, especially in instances where loyalty and creativity are imperative to anchor the academic programme in schools. Henderson and Hoy (1983), in Ben-Sasson and Somech (2015), found that toxic principals are not successful in developing loyalty and trust among the followers.

Finally, the study found that there is a positive relationship among toxic leadership behaviour, followership diligence at work, followership commitment to work, and followership loyalty with followership productivity in Lagos State Senior Secondary Schools. This finding corroborates the findings of Schyns and Schilling (2013) whose results showed the expected correlation between toxic leadership and such constructs as follower outcomes, diligence, commitment, loyalty, being productive and behaviours, resistance toward the leader, retention/turnover, and attitudes. Toxic leadership resulted in negative follower behaviours where followers were not only less productive but outright resistive toward the leader's intentions. What they observed was that followers of toxic leaders engaged in behaviours that were counterproductive to the leader's intent. For the toxic leader, the expected outcomes from the followers' behaviours include decreased performance (Hutchinson \& Jackson, 2015). WilsonStarks (2003) proposed that toxic leaders would have a negative impact on group productivity. While this is anecdotally sensible, some authors have argued that toxic leaders may actually have a short-term positive impact on productivity levels through their negative behaviours. For example, Whicker (1996) described toxic leaders as those who bullied their subordinates into higher levels productivity, forcing them to produce more by instilling fear of the toxic reprisals. Whicker admitted, however, that these gains were short-lived, and conceded that the toxic leadership would eventually lead to subordinate burnout and/or turnover.

Given these findings, it seems plausible that followers of a toxic leader would be less productive and have fewer resources to dedicate to the work group's success.

Compared to the other three key variables (toxic leadership, followership diligence at work and followership commitment at work), followership loyalty has the strongest influence on the followership productivity while the followership commitment has the least. In fact, research has proved that followership loyalty has had a positive impact on the outcome of any organisation. Teachers' loyalty brings efficiency in their working process through which school organisation delivers quality to it students. It has been evident that followership loyalty plays a very important role in improving the performance of an organisation. Frost (2003) observed that follower, who has suffered moral degradation and loss of self-esteem through the actions of a toxic leader, will lose loyalty and confidence to perform good work. Work will not get done, or be sub-standard, innovations will suffer, all of which could result to reduction in productivity. It is observed that followers' loyalty in school setting is the most important element of followership productivity, because it is the key factor that determines the performance of school organisation.

\subsection{Conclusion}

The focus of this study is on toxic leadership behaviours specifically of school leaders. This is not to say that others who follow these school managers in ranks are not in a position to potentially inflict substantial damage on school organisation. The higher the individual is in the school organisation, the more power they have at their disposal, if this power is used to enforce dysfunctional behaviours the consequences could spread through the school organisation because of the legitimate or position power which the individual has from his/her position within the school organisation.

It can be observed that toxic school leaders are extremely dangerous to followers/teachers and also to the sustainability of the schools aims and objectives. Individuals having toxic traits and potentiality of toxic behaviours should not be allowed to occupy leadership positions in school organisation under any circumstances. This brings a lot of responsibility and involvement of permanent secretary of ministry of education and Tutor Generals/Permanent Secretaries in Lagos State Education Districts; they must do everything within their power and influence to prevent an individual or groups of toxic leaders from assuming positions of leadership in schools organisations. Toxic leadership behaviours will not disappear from school organisation easily, they must be driven out by responsible and ethical corporate guardians.

Nigerian generally and Lagos State in particular need to work towards a society in which selection or appointment of school leaders (Principals and Vice-principals) are done without politics and devoid of prebendal arrangements.

The conclusion can be reached from the results and findings that toxic leadership is present in Lagos State senior secondary schools as evidenced in the study no matter how minimal. And that, leadership toxicity seems to be very prevalent aspect of organisations including school, yet it attracts far less focus that it deserves. In the final analysis, toxic leadership behaviour in any school setting, undermine followership commitment to work, followership loyalty which ultimately leading to deterioration in followership productivity, that is the productivity 
of the school will be decreased in terms of students' academic performance. Many a times, the working environments are what trigger leaders towards toxicity to some extent.

\subsection{Recommendations}

Based on the findings of this study, the following recommendations are made.

1. School teachers should be exposed to professional development training and opportunities particularly in leadership before placement for leadership positions, as leadership preparation and training are central to school effectiveness and school improvement.

2. Greater attention should be given to training personnel involved in the search and selection of school leaders.

3. Ministry of Education, Tutor Generals/Permanent Secretaries in Education Districts and other administrators who assist in the screening of candidates for the school leadership positions need more knowledge of the research behind effective leadership in schools and methods developed by organisational psychologists for identifying and recommending persons with leadership potential and not those with toxins.

4. Qualified consultants, that is, personnel specialists with expertise in organisational leadership should be engaged during the search and selection process of school leaders so as to detect toxic leaders in waiting.

5. Appointment or selection of teachers into school leadership positions (Principals or Vice-principals) should be based on past records of the teacher devoid of toxic trace.

6. Stakeholders in education should continue to lay more emphasis on the need for school leaders to exhibit good leadership ability in the day-to-day administration of the school, so as to create non-toxic atmosphere for teachers and thus enhance their productivity.

7. At the follower level, State Ministry of Education through the Education Districts should establish ethics ombudsperson to usually investigate allegations of school leader toxicity in various schools.

Acknowledgements: First and foremost, I appreciate the contributions of my indefatigable and amiable supervisor and academic father, Professor Mubashiru Olayiwola Babatunde MOHAMMED for his academic guidance, dedication and unflinching motivation in the completion of this work despite his tight schedule. And also this article and the research behind it would not have been possible without the invaluable support from my cosupervisor, a father for all, Professor Ayodeji Olasunkanmi ABARI of Department of Educational Management, Faculty of Education, Lagos State University (LASU), Ojo, Lagos, his enthusiasm, knowledge and undiluted attention to details have been an inspiration and kept my thesis work on track. I also specially thank Associate Professor Jide Pius GBENU of the same Department for his unflinching support and his fatherly role, your generosity and expertise have improved this study in innumerable ways.

\section{References}

Aboyassin, N. A., \& Abood, N. (2013). The effect of ineffective leadership on individual and organisational performance in Jordanian institutions. Competitiveness Review. An International Business Journal, 23 (1); 68-84. DOI: $10.1108 / 10595421311296632$

Adu, F. O. Oshati, T. \& Eze, I. (2012). Career advancement, school relation and support factors as determinants of teachers' productivity in public schools in Oyo State, Nigeria. International Journal of Education, 4(4); 27-28.

Atanda, A. I., \& Waheed, O. L. (2006). Fundamentals of School Organization and Classroom Management. Ibadan: Awemark Industrial Printers.

Avolio, B. J. \& Reichard, R. J. (2008). The rise of authentic followership. In R. E. Riggio, I. Chaleff and LipmanBlumen (Eds). The art of followership: How great followers create great leaders and organisations. San Francisco: Joseey-Bass.

Ben-Sasson, D. \& Somech, A. (2015). Observing aggression of teachers in school teams. Teachers and Teaching. 21. 1-17. 10.1080/13540602.2015.1005865.

Burns, W. A. (2017). A descriptive literature review of harmful leadership styles: Definitions, commonalities, measurements, negative impacts, and ways to improve these harmful leadership styles. Creighton Journal of Interdisciplinary leadership, 3 (1); 33 - 52. DOI: http://dx.doi.org/10.17062/CJIL.v3i1.53

Campbell, O. (2002). Educational Planning Management and School Organisation, Lagos: Babs Olatunji Enterprises.

Carmen, A., \& Teodora, V.P (2012). The loyalty card: Issues in Evaluating Loyalty Programme effectiveness. International Journal of Economic Practices and Theories, 2 (3); 153-164.

Chaleff, I. (2008). Creating new ways of following. The art of followership: how great followers create great leaders and organisations. San Francisco, CA: Jossey Bass.

Chen Z. X., Tsui, A.S., \& Farh J.L. (2002). Loyalty to supervisor versus organisational commitment: Relationships 
to employee performance in China. Journal of Occupational Organisation Psychology, 75, 339-356.

David, V. D., \& Darja, K. (2016). Leaders-Member Exchange (LMX): Construct evolution, Contribution, and future prospects for advancing leadership theory. Oxford: Oxford Handbook Online.

Dunkin, M. J. (1997). Assessing teachers' effectiveness. Issues in Educational Research,7 (1); 37-51.

Edo., B. L. \& Nwosu., I. C. (2018). Working environment and teachers' productivity in secondary schools in PortHarcourt metropolis. International Journal of Innovative Psychology and Social Development, 6 (4); 39-49.

Egan, T. M. (2004).The effects of organizational learning culture and job satisfaction on motivation to transfer learning and turnover intention. Human Resource Development Quarterly, 15 (3); 279-301.

Frost, P. J. (2004). Handling toxic emotions: New challenges for leaders and their organisations. Organizational Dynamics , 33, 111-127.

Frost, P.J. (2003). Toxic emotions at work: How compassionate managers handle pain and conflict. Boston, MA: Harvard Business School Press.

Hadadian, Z, \& Zarei, J. (2016). Relationship between toxic leadership and job stress of knowledge workers. Studies in Business and Economics, 11 (3); 84-89. DOI: 10.1515/sbe-2016-0037

Henry, B.C. (2012). Leadership models for effective change management. International Journal of Computer Science and Management Research 1 (4); 817-819.

Hogg, M. A. (2004). Leader-member exchange (LMX) theory. In G. R. Goethals, G. J. Sorenson, \& J. M. Burns (Eds.), Encyclopdia of leadership, 2, 835-840. Thousand Oaks, CA: Sage.

Hoy, A., Hoy, W., \& Kurz, N. (2008). Teachers' academic optimism, the development and test of a new construct. Teacher and Teacher Education, 24, 821-835.

Hutchinson, M., \& Johnson, D. (2015). Organisational Leadership and Change Management. McGraw Hill: Apollos University.

Hyacinth, B. (2014, November 16). The seven types of followers (linkedin). Retrieved from http://www.linkedin.com/pulse/2014/leaders-beware-of-follower.

Ibrahim, M., Ghavifekr, S., Ling, S., Siraj, S., \& Azeez, M. (2013). Can transformational leadership influence teachers' commitment toward organisation, teaching profession, and student learning? A quantitative analysis. Asia Pacific Education Review. Advance online Publication. doi:10.1007/s/2564-013-9308-3.

Ibukun, W.O. (2008): Principles of Educational Management, Akure: Stebak Books and Publishers.

Illies, J., \& Reiter-Palmon, R. (2008). Responding destructively in leadershipsituations: The role of personal values and problem construction. Journal of Business Management. Retrieved from http://psycnet.apa.org/journals/aca/3/1/43/

Inatimi Igbogi (2018). Teachers' welfare and commitment as determinants of productivity in Bayelsa State, Nigeria. International Journal of Scientific Research in Education, 11 (6); 1041-1058.

Isikay, C. (2019). Toxic Leadership. In H. Babacan, \& A Temizer (Eds.), Academic Studies in Social, Human and Administrative Sciences-2019, $\quad 39-50 . \quad$ Retrieved from https://www.researchgate.net/profile/Evren_Ayranci2/publication/331739697_Some_Questions_and_Answ ers Regarding Innovation/links/5c8a4d9c45851564fadd231b/Some-Questions-and-Ānswers-RegardingInnovation.pdf\#page $=52$

Kellerman, B. (2008). Followership: How followers are creating change and changing leaders. Bolton: Havard Business Press.

Kemi, O. (2014). Justice, Care and benevolence as Spurs to employee loyalty. International Journal of Academic Research in Management, 3 (2); 110-125.

Kennedy, N. G. (2016). Motivational strategies and productivity: Lessons of experience from public secondary schools in Kisii County; Kenya. IOSR Journal of Research and Method in Education (IOSR-JRME), 4 (3); 33-38.

Kilic, M., \& Gunsel, A. (2019). The Dark Side of the Leadership: The Effects of Toxic Leaders on Employees. European Journal of Social Sciences, 2 (2); 51-56. Retrieved from http://journals.euser.org/files/articles/ejss_v2_i2_19/Kilic.pdf

Kuenzi, M., Mayer, D. M., and Greenbaum, R. L. (2019). Creating an ethical organizational environment: The relationship between ethical leadership, ethical organizational climate, and unethical behaviour. Personnel Psychology, 1-29.

Kusy, M., \& Holloway, E. (2009). Toxic workplace: managing Toxic personalities and their systems of power. San Francisco: Jossey Bass.

Lipman-Blumen, J. (2010). Toxic leaders: They are plentiful. In G.R. Hickman (Ed). Leading Organisations: Perspectives for A New Era ( $2^{\text {nd }}$ ed $)$. Washington, D.C: Sage.

Lipmen-Blumen, J. (2005). The Allure of toxic leaders. UK: Oxford University Press.

Mathieu J. E \& Baniak M. (2016). A review and meta-analysis of the antecedents, correlates and consequences of organizational commitment. Psychological Bulletin 108: 171-194.

Mehta, S., \& Maheshwari, G.C. (2014). Toxic leadership: Tracing the destructive trail. International Journal of 
Management, 5 (10); 18-24.

Mullins, J. \& Linehan, M. (2005). Leadership and followership in Public libraries: Transnational Perspectives. The International Journal of Public sectors Management, 18 (7); 641-647. https://doi.org/10.1108/09513550510624095

Musibau, A. J. \& Adigun, J. T. (2010). Influence of school climate change on teachers' productivity and students' achievement. Journal of Research in National Development, 8, 2.

Nir, A. (2002). School-based management and its effect on teacher commitment. International Journal of Leadership in Education, 5, 323-341.

Northouse, D. G. (2007) Leadership: Theory and Practice (4th Ed). Thousand Oaks: Sage Publications.

Northouse, P. G. (2013). Leadership: Theory and Practice (6th Ed). Thousand Oask; Sage Publications.

Oyegoke S. A. (2012). Private cost and effectiveness of secondary school education in Ondo State, Nigeria. An Unpublished Thesis Adekunle Ajasin University, Akungba Akoko.

Padilla, A., Hogan, R. \& Kaiser, R. B. (2007). The toxic triangle: destructive leaders, susceptible followers, and conductive environments, The Leadership Quarterly 18, 176-194.

Park, I. (2005). Teacher Commitment and its effects on student achievement in American high schools. Educational Research and Evaluation, 11 (5); 461-485. DOI: 10.1080/13803610500146269

Pelletier, K. L. (2010). Leader toxicity: An empirical investigation of toxic behaviour and rhetoric. Leadership, 6 (4); 373 - 389. Retrieved from http://lea.sagepub.com/content/6/4/373

Purcell, J., Kinnie, N., Hutchinson, S., Rayton, B. \& Swart, J. (2003). Understanding the People and Performance Link Unlocking the Black Box. London: CIPD, 56.

Reed, G. E (2004). Toxic Leadership. Military Review, 48, 67-71. Retrieved from https://www.armyupress.army.mil

Rockstuhl, T., Dulebohn, J., Augustine S., \& Shore, L.M. (2012). Leader-Member Exchange (LMX) and Culture: A meta-Analysis of Correlates of LMX and culture: A meta_Analysis of correlates of LMX Across 23 countries. Journal of Applied Psychology 97 (6); 1097.

Schmidt, A. A. (2008). Development and validation of the toxic leadership scale. Unpublished masters thesis, University of Maryland, College Park, MD.

Schyns, B., \& J. Schilling (2013). How Bad Are the Effects of Bad Leaders? A Meta-analysis of Destructive Leadership and Its Outcomes. The Leadership Quarterly 24: 138-158.doi:10.1016/j.leaqua.2012.09.001.

Shondrick, S. J., \& Lord, R.G. (2010). Implict Leadership and followership theories: dynamic structures for leadership perceptions, memory and leader-follower processes. In G.P Hodgkinson and J.K. Ford (eds). International Review of Industrial and organisational Psychology. Birmingham, UK: Wiley Balckwell.

Steele, J. P. (2011). Antecedents and Consequences of toxic leadership in the U.S. Army. A two year review and recommended solutions. Centre for Army Leadership. 1-37.

Tayla, B. \& Berrin, E. (2015). The Oxford handbook of Leader-Member Exchange. New York: Oxford University Press.

Tepper, B. J. (2007). Abusive supervision in work organisations: Review, synthesis, and research agenda. Journal of Management, 33 (3); 261-289. doi:10.1177/0149206307300812

Thien, L., Razak, N., \& Ramayah, T. (2014). Validating teacher commitment scale using a Malaysian Sample. SAGE Open, April-June, 2014;1-9

Toor, S. R., \& Ogunlana, S. (2009). Ineffective leadership: Investigating the negative attributes of leaders and organisational neutralizers. Engineering, Construction and Architectural Management, 16 (3); 254-272. doi: $10.1108 / 09699980910951663$

Van Breukelen, W., Schyns, B., \& Le Blanc, P. (2006). Leader-Member Exchange theory and research: Accomplishment and future challenges. Leadership, 295-316.

Wicker, M. (1996). Toxic leaders: When organisations go bad. Westport CT: Praeger.

Wilson-Stark, K. Y. (2003). Toxic leadership, Retrieved from transleadership. Retrieved from http://www.transleadership.com/Toxic Leadership.pdf 